\title{
Gardeners, locavores, hipsters, and residents: An alternative local food market's potential for "community" building
}

\author{
Yuki Kato* \\ Tulane University
}

Submitted March 15, 2014 / Revised July 2 and August 4, 2014 / Accepted September 1, 2014 /

Published online December 10, 2014

Citation: Kato, Y. (2014). Gardeners, locavores, hipsters, and residents: An alternative local food market's potential for "community" building. Journal of Agriculture, Food Systems, and Community Development, 5(1), 145-159. http://dx.doi.org/10.5304/jafscd.2014.051.013

Copyright (C) 2014 by New Leaf Associates, Inc.

\begin{abstract}
The term community is frequently cited in the mission statements of alternative food projects, though what it signifies in vision and practice is rarely made explicit. This case study examines an alternative food market in a New Orleans neighborhood that operates a market that is modeled after CSA and on-site community gardens. Based on ethnographic observation and interviews with community gardeners, market staff, volunteers, customers, and local residents, this paper explores different views of "community" in relation to the market's practices. Data analysis identified four communities in relation to the organization: community gardeners, conspicuous locavores, hipsters, and local residents. The paper shows how each community has a distinct set of expectations for the organization's role in the community and demonstrates that some of them value enhancement of social connections through their
\end{abstract}

* Yuki Kato, Department of Sociology, Tulane University; 220 Newcomb Hall; New Orleans, Louisiana 70118-5698 USA; +1-504-862-3010; ykato@tulane.edu involvement with the organization more than others. The findings do not demonstrate a unified community emerging around this organization; none of the communities has staked a claim yet on the organization. Some missed opportunities for bridging these communities can be attributed to the operational and physical structures of the organization, some of which, ironically, were intended to enhance community involvement. On the basis of these findings, I conclude that the alternative food movement may not necessarily create a unified community with shared goals, but this should not necessarily be considered a failure of community building. I also call for alternative food scholarship and praxis to examine the movement's impact on individuals and groups beyond the core, committed members.

\section{Keywords}

alternative food networks, community development, community gardening, community supported agriculture, CSA, food justice, urban agriculture 


\section{Introduction}

The last decade has witnessed the rising popularity and visibility of alternative food networks (AFNs) and various urban agricultural activities, such as urban gardening, farmers markets, and communitysupported agriculture programs (CSAs) in the United States. Some scholars who have examined AFNs have focused on the meaning of "community" in relation to urban agriculture (e.g., Alkon \& McCullen, 2011; Lyson, 2004; Macias, 2008; Schmelzkopf, 1995). Lyson (2004) advocates "civic agriculture" as a way of reconstituting the relationship between agricultural production and consumers in order to have more direct and locally oriented food production and distribution. DeLind (2002) builds on this notion of community engagement and encourages development of nonmarket aspects of the grower-consumer relationship.

In practice, AFN organizations often cite "community" in their mission statements, despite the multifaceted definitions of this term (Kurtz, 2001; Nettle, 2014). Studies have explored which operational structures of AFNs enhance interactions among the participating individuals (Kurtz, 2001; Macias, 2008) and how a sense of community is experienced by community gardeners, CSA members, or farmers market patrons (Glover, 2004; Ostrom, 2007; Saldivar-Tanaka \& Krasny, 2004). Other studies have investigated the extent to which community engagement motivates AFN participants to become socially active (Cox, Holloway, Venn, Dowler, Hein, Kneafsey, \& Tuomainen, 2008) or how the social impact of AFN activities may extend beyond gardening or distributing food and enable mobilization toward other social issues faced by the community (Armstrong, 2000; Nettle, 2014; Ohmer, Meadowcroft, Freed, \& Lewis, 2009).

In many studies of AFNs' community-building potential, the focus has been on the AFN's impact on those who are committed to the movement as organizers, volunteers, or even consumers (e.g., Kingsley \& Townsend, 2006; Kurtz, 2001; Nettle, 2014) and less on those who are less involved or simply in geographic proximity to these activities. In this paper, I investigate how individuals on the periphery of the movement may view and anticipate AFN activities' impact on their communities, with particular attention to the movement's poten- tial for bridging disparate communities. Based on interviews and ethnographic observation at an alternative local food market with on-site gardens in New Orleans, I identify four distinct communities in relation to the organization. In the concluding section, I return to the way that AFN scholarship has defined and assessed the movement's community-building capacity and propose a broader definition of community that focuses on the movement's effects on the values and actions of the less committed participants.

\section{AFNs' Community-Building Potential}

Studies of AFNs' capacity for community development thus far have conceptualized community as two general constructs: as a community of involved participants centered around a particular AFN project, such as a community garden or CSA, or as a residential unit or a social group with whom the AFN project's mission statement aims to engage. Overall, the literature suggests that not all AFN activities have community-building capacities, though some AFN projects have been more effective than others in fostering social capital or a sense of community among the participants. This section reviews the previous research on the factors that affect an AFN's community-building potential and examines how these studies define and measure "community."

Regarding the conceptualization of community as a group of involved participants, scholars have examined the social connections and values ascribed to the relationships among the organizers and committed supporters of AFN activities, such as community gardeners and CSA members (e.g., Allen, Alaimo, Elam, \& Perry, 2008; DeLind, 1999; Nettle, 2014). "Community development" in these studies is often defined as the quality and quantity of social capital that the activity produces (Glover, 2004; Kingsley \& Townsend, 2006; Macias, 2008), although this way of defining and identifying community in relation to an AFN may not fully capture the complexity of the concept as it is understood and negotiated by the participants (Kurtz, 2001; Nettle, 2014). Social capital, as operationalized by Putnam (2000), refers to social connections that foster civic engagement, while Bourdieu's (1984) use of the term highlights how 
an individual's social ties inform his or her cultural practices, which serve as a mechanism of social distinction. Both definitions are relevant to AFN participants' social ties because social capital serves as the motivation of their engagement with the movement, yet these connections may occur in an insular circle of like-minded people.

The extent to which these individuals develop social capital depends in part on the project's operational structure. For example, studies of CSAs find that without an explicit commitment structure, member participation as volunteers on the farm or in other aspects of the operation tends to be low, especially among those whose enrollment was motivated by subsidized membership and not ideological commitment (Andreatta, Rhyne, \& Dery, 2008; Hinrichs \& Kremer, 2002). But among strongly committed CSA members, direct contact with the farmers and other members, many of whom are middle-class and highly educated, could foster strong relationships (Cox et al., 2008; Macias, 2008; Ostrom, 2007). Among AFN activities, community gardens are associated with stronger social capital development (Glover, 2004; Nettle, 2014; Saldivar-Tanaka \& Krasny, 2004) because gardeners work in the same space and share tools and responsibilities (Macias, 2008). Nevertheless, some of these connections may be experienced only within the context of gardening and not in the participants' general social activities (Kingsley \& Townsend, 2006). While farmers markets can provide a place for direct interactions between farmers and consumers (Alkon \& McCullen, 2011; Macias, 2008), thus creating a strong sense of community, the racial and class exclusivity of these markets (Alkon \& McCullen, 2011; Guthman, 2008; Slocum, 2007) could hinder participation by non-White, lower-income consumers, thus limiting the potential to build connections across racial and class lines. In addition to the operational structure, the physical structure of an AFN project could affect the level and quality of social interactions among the participants. Tending individually assigned garden beds results in less interaction with other gardeners than working on communal gardens (Kurtz, 2001), for example, and fencing and locked gates physically and symbolically exclude outsiders, including nearby residents
(Schmelzkopf, 1995).

When community is conceptualized as a spatial or social unit that is not based on association with an AFN, the project's impact on building community refers to the project's relationship with residents of the surrounding area or members of particular racial, ethnic, or income groups. It can also involve the potential of the AFN project to foster social ties within these communities. Some AFN projects explicitly aim to serve a particular community conceptualized in this way (Glover, 2003; Saldivar-Tanaka \& Krasny, 2004), while others work with nearby residents as a part of their daily operations (Nettle, 2014). For some AFN participants, their engagement with the AFN motivates them to expand their community involvement beyond AFN activism (Armstrong, 2000; Ohmer et al., 2009). Some urban agricultural projects are established explicitly to address broader social issues, such as racial and ethnic inequalities (Morales, 2011; White, 2010), although these projects remain the exception.

Urban agricultural projects could be employed as part of a social mobilization "repertoire" (Nettle, 2014) that plants the seeds for community organizing toward broader social issues. However, studies of the communities being built through these projects have largely focused on the perceptions and experiences of the committed participants. Less understood is the experience of the peripheral participants, especially those who do not strongly identify with the AFN ideologies despite their social or physical proximity to the project. These individuals may include nearby residents, occasional volunteers, or customers of CSAs, community gardens, or farmers markets. It is not surprising that people who are committed to AFN ideologies develop strong ties with like-minded folks. But to understand how participation in AFNs may contribute to the forging of new social ties and a sense of solidarity, investigating how these activities affect less committed individuals is important.

Finally, researchers who have studied AFNs' community-building capacity tend to evaluate community building by examining whether the participants form a cohesive community centered around an AFN project. However, a project may develop multiple communities among different participants, 
depending on their identification with the project or AFN ideologies in general, and their expectations of what AFNs represent. In this study, I pay close attention to which "community" individuals have in mind when they discuss their relationship to an AFN organization or to others involved with the organization.

\section{Study Site and Research Methodologies}

This article draws data from a qualitative case study conducted at an alternative food market. The study was designed to combine two qualitative data collection methods, ethnography and interview, to examine the market's daily routines with a particular focus on its engagement with the surrounding community. Hollygrove Market and Farm (HMF) ${ }^{1}$ is located in the Hollygrove neighborhood in the northwest corner of New Orleans. A local community development corporation established the market to address the lack of access to fresh produce in the area in 2008, following Hurricane Katrina.

At the time of the data collection, three fulltime staff members operated the organization with assistance from volunteers in running the markets and maintaining the facility. Its business model combines elements of a CSA and a farmers market. Unlike at a farmers market, growers do not sell produce to the customers themselves. The market buys produce from local and regional growers throughout the week. The market has on-site gardens, and some items grown there are sold at the market's "growers' table." The market offers a CSA-style produce box for US $\$ 25$ per week. For example, one week's box included sweet potatoes, shiitake mushrooms, radishes, spinach, Brussels sprouts, tomatoes, green onions, Swiss chard, mixed salad greens, and a half-dozen eggs. However, unlike conventional CSAs, on any market day customers may purchase a box without membership or advance payment. Customers may also purchase individual items, and the market has increased the variety and volume of these items over the years. The market also sells dairy products,

\footnotetext{
${ }^{1}$ This is the actual name of the neighborhood and the organization. Pseudonyms are used for individuals quoted in this article to protect their identities.
}

bread, pies, and other value-added goods. At the time of the study, on-site market hours were held three times a week: at midday on Saturdays and Sundays and on Tuesday afternoons.

For the ethnographic component of the study, the author and two research assistants worked at HMF as volunteers between June 2010 and December 2011. We worked alongside other volunteers doing jobs that ranged from collapsing cardboard boxes to bagging or bundling produce items into specified portions, setting up and maintaining produce baskets during the market hours, and cleaning up. After each observation, which generally lasted 3 to 6 hours per visit, we wrote field notes to describe in detail what we saw and heard, using the grounded-theory method (Glaser \& Strauss, 1999). This method emphasizes fieldwork that is not limited by preconceived frameworks or hypotheses but in which the research topics and foci emerge out of keen, objective empirical observations.

I also conducted 30 in-depth, semistructured interviews during fall 2011 with five current and former full-time staff members, six volunteers, seven customers, and six on-site gardeners of HMF. I interviewed 10 residents of the Hollygrove neighborhood, three of whom were on-site gardeners. Interviewees were recruited through several sources. I approached all full-time staff members, and all of them consented to be interviewed. Among the gardeners, those who tended the gardens most regularly, based on ethnographic observations, were recruited for the interview. In determining which volunteers and customers to interview, I used quota sampling to ensure that people who volunteered or shopped on various days and at various times were included. One Tuesday and one Sunday during the same week, I approached one customer approximately every 30 minutes until I had a sufficient number of customers who consented to being interviewed. Similarly, I recruited volunteers on different days during the same week, some of whom I knew as frequent volunteers and others with whom I had never volunteered before. The interview questions asked the interviewees to describe their experiences of working or shopping at HMF, their motivations for getting involved (or not, in the case of some resi- 
dents), and their expectations and suggestions regarding HMF's practices.

Both the field notes and the transcribed interviews were coded using Atlas.ti qualitative data organization and analysis software, which accommodates open coding based on the grounded-theory method. Throughout this paper, quotations in italics denote statements from my field notes, which try to duplicate what people said. Because they may not be verbatim quotations, they are distinguished from the interview quotes. The interview quotes were selected on the basis of their representativeness among the interviews to illustrate the varying views of the "community" that HMF is expected to serve.

In addition to the interviews and the ethnographic data, I will also draw data from the survey that I conducted of $147 \mathrm{HMF}$ customers as a preliminary data-collection process for the study. I surveyed the customers on a Tuesday and Saturday of the same week during spring 2011. The 25 questions on the survey covered topics such as customers' demographic information, their general food consumption behaviors (e.g., where they shop for groceries, how often they cook at home, what matters most when deciding what food to buy from which vendors), their motivations for and experiences of shopping at HMF, and their expectations for HMF. While the primary focus of the survey was not to study the customers' views on "community" in relation to HMF, I refer to the descriptive statistics of the responses to a few of the survey questions that are relevant to this article.

\section{Hollygrove Market and Farm and Its Community-Building Visions}

In examining HMF's community-building capacities, it is apt to begin with its mission statement:

Hollygrove Market and Farm exists to increase accessibility of fresh produce to Hollygrove, surrounding underserved neighborhoods, and all of New Orleans while promoting sustainability through support of local farmers and the local economy as well as acting as a demonstration site for environmentally sustainable practices. (Hollygrove Market and Farm, n.d.)
The statement does not explicitly use the term community but refers to three geographical areas in expanding order: the neighborhood where HMF is located, "surrounding underserved neighborhoods," and the entire city. The list does not make clear how high a priority is placed on increasing the access to fresh produce in the Hollygrove neighborhood. It also mentions "local farmers," though how the locality is defined is not specified; it could refer to urban growers as well as farmers outside the city, especially in rural agricultural regions of southeast Louisiana. Its mission mentions raising awareness about environmental sustainability but stops short of establishing HMF as a leader in organizing citizens around this topic. Overall, therefore, HMF's goals seem to be focused on the redistribution of locally grown food and on environmental sustainability, and not on building community, although the former does involve developing transactional links between growers and consumers.

When speaking with the staff members, however, I learned that they have variable visions of the role that HMF plays, or ought to play, in building communities - and more importantly, which communities they had in mind. Nate, a White staff member in his late 20 s, told me several times during the interview and in my interactions with him during the fieldwork that he saw HMF as a community organization for the Hollygrove neighborhood. On one occasion during my fieldwork, our conversation led to the discussion of the market's popularity among the "Uptowners" from the wealthier section of the city. Nate told me that he thought it was fine that they dominated the market as customers but that "my goal is to get people to come to the market, so when they sign up to volunteer, we can get them to also belp out in the neighborbood." He worked closely with some neighborhood organizations, including senior citizens' groups, and helped host their meetings at the market's space during nonbusiness hours while the senior center, which was severely damaged during Hurricane Katrina, was under reconstruction. Thus he viewed HMF as a neighborhood organization whose market operation was just one aspect of how it funneled resources into Hollygrove and provided services to the neighborhood residents. 
In contrast, Paula, a White staff member in her 30s, did not mention the Hollygrove neighborhood during our interview, and focused more on the local food growers and consumers in the city and the region. For example, asked if she knew where the neighborhood boundaries were, she responded, "I don't know, but [her partner] does." She also used the word "Hollygrove" during the interview to refer to the market, which many customers and volunteers did, while other staff typically called it "Hollygrove Market" to distinguish it from the neighborhood. Residents, on the other hand, commonly referred to HMF as "the farmers market" without including the neighborhood's name in the reference.

Jess, a White staff member in her 20s, saw HMF as helping local growers, as well as the Hollygrove neighborhood, but with a more specific focus on local food production and consumption. In my conversations with her, during both the interview and the fieldwork, it was never clear to me whether she prioritized one over the other. She spent more time working with the growers in her day-to-day management of the market, but she got very excited every time someone from the neighborhood approached her with produce grown in the neighborhood or value-added goods to sell, such as jars of jelly or pies. But her concerns about the neighborhood tended to be on specific issues of food production and consumption, rather than broader issues in the community. For example, she viewed the abundance of vacant lots in the neighborhood as having a huge potential because "that would be ideal, to really start getting some training to neighborhood members that express interest, and have them take over their own lots, then sell it [the produce being grown in these spaces] to us, so be able to support themselves."

In discussing their relationship with the neighborhood, Jess and most other young, White staff members expressed reservations about deciding what the neighborhood should do because none of them lived in the neighborhood and they were acutely aware of the racial and age differences between the residents and themselves. Thus hiring someone from the neighborhood was important to many staff members, who felt that their overwhelming whiteness and lack of credentials as "natives" posed problems in building rapport or representing the neighborhood. Unfortunately, efforts to recruit residents for staff positions often failed. One of the resident community gardeners was recruited to be the lead gardener, but he declined the offer, suggesting that he did not want the responsibility, according to the staff and other gardeners. Vera, a community gardener and parttime staff member in her 60s who identifies as racially mixed, recalled HMF's effort to hire someone who was non-White from the neighborhood. She told me that HMF identified one person who fit the description, but "that person never called back." She then pointed out that "they did make an attempt. That's all I can ask for, if you tried to remedy that."

Overall, HMF staff exhibit varying ideas about which community HMF is meant to engage and whether community building should be a priority. Given this variation, it is not surprising that HMF does not yield a unified community centered around it. Nevertheless, I found that HMF does provide opportunities for several smaller, distinct communities to form through its practices. In the subsequent sections I describe what each of these communities derived from HMF and discuss the extent of these communities' interaction with each other. In doing so, I discuss the operational and structural characteristics of HMF that may have contributed to opportunities and limitations in forging new connections among the individuals who are in social or geographic proximity to HMF.

\section{Community Gardeners, Conspicuous Locavores, Hipsters, and Local Residents}

I identified four communities in relation to HMF

based on people's motives for engaging (or not engaging) with the organization: community gardeners, conspicuous locavores, hipsters, and local residents. In the following section I describe the social interactions among the members of each community and illustrate, using excerpts from the interviews and field notes, the role that HMF plays or is expected to play, from the perspectives of various individuals, for each community. The description of these communities as typologies is meant to organize the modes of participation and expectation theoretically; they are not intended to 
classify any particular individual. Not everyone who is involved with HMF or lives nearby belongs to one of the four communities, and a single individual may exhibit characteristics of multiple communities.

\section{Community Gardeners}

The community garden plots at HMF are available to anyone, and Hollygrove residents were tending approximately a third of the 16 plots (each 8 feet by 20 feet, or $2.4 \mathrm{~m}$ by $6.1 \mathrm{~m}$ ) at the time of the data collection. The gardeners from the neighborhood are mostly African American retirees, while other gardeners are almost exclusively White and middle-aged or younger. Some grow food for their own consumption, while others sell the produce and plants to HMF or to other customers in varying quantities. Two Mentor Farmers, who provide guidance to the community gardeners, have larger plots on-site.

When discussing their experience at HMF, many gardeners expressed how much they learned from each other, especially from the more experienced gardeners. The community gardeners I met had been gardening for only a few years. For these novice gardeners, receiving hands-on instruction in urban agriculture was essential. Don, an African American gardener and Hollygrove resident in his 60 s, took up gardening at home and at the community garden shortly after HMF opened. He described his experience at HMF as follows:

You know, I never grew mustard greens or spinach, lettuce....[A mentor farmer], he's an asset. [The other mentor farmer], he's an asset. You know, you can go to these people and ask them questions, real growing questions, and they would have answers for you, or they would lead you down the path where you can go out and get what you need.

But these interactions primarily focused on exchanges of horticultural knowledge, or what Macias (2008) calls "natural human capital," and did not develop into a cohesive identity as a gardener community or an HMF community. Don also described how gardening was therapeutic for him to relieve his anger over his troubles with the contractors rebuilding his flood-damaged house. During the ethnography observation period, I often found Don and other gardeners pleasantly conversing with the market customers strolling through the garden. Nevertheless, during the interview he did not talk about his interaction with the HMF visitors as being of particular importance to him, compared to the emphasis he placed on the personal therapeutic and health benefits of gardening.

Like Don, many gardeners viewed HMF as providing a space for their cultivation activities, as well as a way to make money by selling their produce. Karen, another senior African American gardener from the neighborhood, appreciated having the garden plot because it gave her "something to do" as a "pastime." She responded to the question "Do you see a lot of people out here in the garden when you come?" by stating:

We used to have a nice time just with the gardeners. Everybody doing their own thing, and we could see them and talk and stuff of that nature. And then they had people come in and look at it, especially on Saturdays [during the market hours] I'm not here too much on Tuesdays [another market day], but even on a Tuesday, you have the children come. Kids come with their instructors and come and look at the garden. They, some of the employees, will show them around and educate them about the garden and stuff of that nature.

As Karen describes it ("everybody doing their own thing”), gardeners keep to their assigned individual plots while enjoying pleasant copresence with other gardeners. The gardeners' descriptions and my observations suggest that the relationships among the gardeners rarely extend beyond the HMF space and are often instrumental in nature, with an exclusive focus on gardening. As previous studies have shown (Kurtz, 2001), this situation may be partially due to the individual plot format of the gardens at HMF. Although the gardeners share knowledge and tools, and occasionally have meetings to discuss rules and expectations about how to maintain 
the garden, they work independently and on their own schedule.

The remainder of Karen's response describes her observation of people who come into the garden space, including HMF market customers and schoolchildren on field trips. As she points out, tours of the garden are typically led by HMF staff rather than by gardeners, though I often observed the gardeners showing interested adult or young visitors around the garden and even letting children pick small items from their plots on occasion. In doing so, however, the gardeners did not necessarily represent HMF, as indicated by their reference to HMF as "them," not "us."

Despite her positive description of the interaction with other gardeners or visitors, Karen, like other gardeners, mostly talked about what she was currently growing and how much she enjoys being in the garden. Thus, while the gardeners appreciated friendly interactions among themselves and with the market visitors, they did not describe themselves as a distinct group with a shared identity as community gardeners; rather they mostly saw HMF as a great place to get instruction on gardening that enhanced their own horticultural knowledge and skills.

\section{Conspicuous Locavores}

Among the customers and volunteers, the attitudes and practices of the group that I call conspicuous locavores take on a characteristic of conspicuous consumption (Veblen, 1899), whereby eating local food becomes an expression of cultural capital rather than a means of subsistence. The survey of the customers indicated that access to locally grown food was most likely to be selected as one of the top two reasons for why they shop at HMF (45.6 percent selected this reason), followed by support for local growers (27.9 percent). Other reasons, such as access to food that tastes good (12.2 percent), organic food (9.5 percent), seasonal food (6.8 percent), support for local businesses (8.2 percent), concerns for the environment (6.8 percent) and health (5.4 percent), were also selected. However, "Being part of the community" received the least number of responses as one of the top two reasons for shopping at HMF a 2.7 percent. While not all customers qualify as conspicuous locavores, the survey data indicate that most customers are not motivated by their desire to be a part of HMF community.

This does not mean, however, that the locavores, many of whom are customers, do not find any value in communities in relation to HMF, as I found in my interview data. The sense of community that the locavores feel at the market is directed toward like-minded people, and within this context they were most eager to interact with other locavores. This sentiment was expressed by Bea, a White customer in her 30s:

This has created a neat sense of community for me... Someone that has the same concerns as you do, whether it's just brushing shoulders, it's just kind of empowering in that way. Being able to go to that place every week and having just small conversations with people, you just go ah, yeah.

Although she had moved to New Orleans only a few months before being interviewed, Bea had been regularly shopping at HMF since she found it on the Internet when searching for an alternative food market. For her, shopping at HMF was not solely about access to locally grown fresh produce but about interactions with other customers with whom she felt that she shared values. That locavores feel a sense of belonging in the market's space is not surprising given the cultural and ideological homogeneity among many farmers market and CSA customers identified in previous studies (Alkon \& McCullen, 2011; Guthman, 2011; Slocum, 2007). However, as Bea's example indicates, this friendly interaction tended to remain superficial and fleeting in nature.

Similarly, some locavores enjoyed talking with the gardeners and admiring their gardens, but did not mention the importance of the on-site gardeners' participation as growers for the market. In contrast to the value that the direct agricultural market places on the symbolic "embeddedness" (Hinrichs, 2000; Winter, 2003) of local food, the locavores at HMF did not express a strong desire to interact directly with the growers. Some considered the gardens' proximity a benefit to the farmers ("They can focus on growing instead of driving for 
hours"), and others suggested that the format of the market box was more efficient than a standard farmers market in which customers have to go from table to table before deciding what to buy from whom. They also expected HMF to "do the job" of screening the produce so that they could assume the products meet standards for being "locally grown" or "organic."

Conspicuous locavores are more invested in HMF's role in a broader community of locavores in the city rather than the immediate Hollygrove neighborhood. Almost all nonresident interviewees suggested that they would like to see more Hollygrove residents shopping at HMF. Yet, when asked if HMF should further reduce the price of the produce, in addition to the resident discount, their responses remained ambivalent. Carol, a White female in her 20 s who volunteers a few times a month at the market, responded:

Well, it seems like their goal is just to provide local food to the community - maybe not specific to that neighborhood, but New Orleans. Help New Orleans, like Uptown and Mid-City, and provide support for local famers who are selling the products to them.

According to the survey of customers, approximately one third of the market's customers reside in Uptown and Mid-City, which are middleclass neighborhoods in the city. Like Carol, many locavores tended to positively evaluate HMF in terms of its significance to the locavore community. Nora, a White female customer in her 30s who has volunteered at HMF several times, but not regularly, responded to the same question by stating:

I think it depends on what their mission is. And I don't actually know what their stated mission is. I mean, personally, I think there's a huge need to get healthier foods in

\footnotetext{
${ }^{2}$ Many customers assumed that all the items sold at HMF were organic, though this was not the case. The items that were organically or naturally grown were labeled as such, although the market does not apply the label "conventional" to other items. Volunteers were often aware of the differences.
}

their [neighborhood]. So I would love to see that. But if their mission is just to sell fruits and vegetables from local farmers to whoever will buy them then it's a different type of organization if it's one or the other.

Such statements indicate that while expressing concerns regarding the social impact of HMF's operations, locavores do not feel strongly about its priority over the immediate service that matters most to them: making local food available. More importantly, their deferral of the decision to HMF, as indicated by the use of "them" in reference to HMF, suggests that they do not view themselves as stakeholders of the organization.

\section{Hipsters}

Compared to the conspicuous locavores, whose focus is on local food consumption, hipsters ${ }^{3}$ are drawn to HMF as a part of their anticorporation and anti-mass production ideologies that extend beyond food-related concerns. Some would ride bicycles rather than drive to the market, for example, even in the sweltering heat of a New Orleans summer. While their representation at the market was less than that of conspicuous locavores, their presence was more prominent among the volunteers. I did not gather any systematic demographic information on this community, especially because the individuals who exhibited these attitudes did not necessarily always self-identify as part of this group, but through interactions and observations during my fieldwork, I learned that many of these young adults had moved to New Orleans within the three years prior to the data collection period.

Hipsters are as conspicuous about their commitment to buying local food as locavores are, but I found in their narratives an emphasis on their conscious choice to shop local despite their limited budget. Kendra, a White regular volunteer in her

\footnotetext{
${ }^{3}$ I use the popular cultural vernacular for this group with some hesitation, as the individuals I place into this category may not themselves identify with the label (Greif, 2010). The description of this community, therefore, is not meant to describe the hipster subculture at large but focuses explicitly on its intersection with HMF.
} 
20s, described the differences between the conspicuous locavores and hipsters (although she did not use these terms) among the HMF customers:

It's a really interesting like display of different folks. I feel like a lot of it is pretty white and pretty at least like upper middle class. Then, there's, like, a decent number of, like, young, white people like me who are, like, poor, but still want to make sure that their money is going to good cause.

Their lack of funds to purchase local food partly explains why some hipsters volunteer at HMF. The volunteers at HMF receive a free produce box for 3 hours of work. As Colin, who volunteers once a week, pointed out, "I know I would not be shopping at Hollygrove if I didn't volunteer and get this basket of produce as part of my work." For Colin and others, their work served to validate their efforts to acquire food they otherwise could not afford, and HMF's volunteer opportunity enabled them to exhibit such commitment. In contrast, many of the locavores indicated during the interview that they had not volunteered at HMF, citing lack of time or interest. The survey found only 5.4 percent of the customers had ever volunteered at HMF. When asked if they planned to volunteer at HMF in the future, 17.0 percent marked "Definitely will volunteer," while 53.1 percent marked "Maybe will volunteer." Among the 24.5 percent of the customers who marked "Maybe will not volunteer" (15.0 percent) and "Definitely will not volunteer" ( 9.5 percent), 34.0 percent cited "I don't have time" as their reasons for not planning to volunteer at HMF, while only 3.4 percent indicated "I'm just not interested." In this regard, HMF's decision not to require membership or volunteering, unlike typical CSAs, in order to lower the bar for participation, seems to have resulted in an expansion of the business to customers who did not feel compelled to get involved with the organization.

When asked why they volunteer, however, many hipsters emphasized the importance of doing "something good," not just obtaining the free box of produce. Mariella, a White regular volunteer in her early 20 s, described her motivation:
I mean, the free food probably does something, but, at least for me, there's a good probability I would be there without the incentives, and I think that's true of other people I have met who are there. It's almost like something you can do that's productive and you can feel like you've done something good.

Interestingly, however, despite their desire to "do something good" and their friendly interactions with one another, the hipster volunteers did not typically express a strong desire to "be part of the HMF community" or to engage with the Hollygrove neighborhood. Compared to the locavore volunteers, many of whom enjoyed conversing with other locavores about their enthusiasm for locally grown food, the hipster customers or volunteers did not interact with others with the same level of enthusiasm. Based on my interactions with them and observation of their in-group conversations, I also found that their interests expanded beyond food to larger social issues of inequality, the environment, and mass consumer culture.

Given their own financial constraints, one would anticipate them to be more empathetic toward the residents who could not afford to shop at HMF. Rather, their efforts to overcome economic challenges reinforced their notion of food access as a choice, while they also viewed the economic disadvantages of the low-income community to be beyond HMF's capacity to address. As Kendra put it,

I don't think that, like, Hollygrove is doing something like terribly wrong and if they were doing something better that the Black folks would be flocking to the market. I think that there's, like, a bigger problem, a bigger wall in the way that's, like, social and cultural, and economic and lots of big college words.

Coupled with their celebration of individual solutions to their own financial limitation, such sentiments by the hipsters echo the neoliberal ideologies that some scholars have argued perme- 
ate the alternative food movement (Alkon \& Mares, 2012; Hinrichs \& Eshleman, 2014).

\section{Local Residents}

The Hollygrove neighborhood, where HMF is located, suffered significant damage from the flooding that followed Hurricane Katrina. The population has not returned to its pre-Katrina level; it is at 63 percent of the pre-Katrina population, with 92 percent of the approximately 4,000 neighborhood residents identifying as Black or African American (The Data Center, 2014). Most Hollygrove residents I interviewed or interacted with during this study were aware of HMF, although they told me that many of their neighbors did not know that the market existed or were unsure about its practices. Even among interviewees who had visited the market, some had visited only once or twice and decided that it did not suit their needs. Louise, a resident interviewee in her 60s, suggested that the CSA-style box sold at the market did not suit her way of shopping:

One of the things that I think the individuals here in the community complain about [regarding HMF] is that we want to be able to purchase what we want individually and not in a box or a basket, you know? Let us do it that way. That's what I'm used to doing.

Issues that kept Hollygrove residents away from the market, based on the interviewees' assessments, included the price of the produce, which they considered too high, and the rigidity of the produce box system, as Louise pointed out. Interestingly, her comment reveals that she was unaware that options other than the produce box had been available at the market for at least a year at the time of the interview. Another interviewee wondered aloud how many people in the neighborhood knew about the resident discount, and thought HMF should do more advertising in the neighborhood to publicize the program. HMF's limited business hours, combined with senior citizens' limited mobility due to both physical weakness and lack of vehicle ownership, posed additional barriers to access.
Many resident interviewees who had not shopped, gardened, or volunteered at HMF still knew about it because of the community meetings held there. When I attended the meetings, the agendas included issues of concern to the residents, such as reopening of the neighborhood elementary school that had been closed since Katrina, rebuilding a playground, or public safety. One resident interviewee in her 60s, Alice, described her surprise when she first visited the HMF space during the market hours:

We used to go on, I think it's Wednesday night, Thursday night, to the meetings we have over there. And it would just be us. And then one time we went over there on a Saturday because we trying to raise money for the seniors. And I was amazed at the people coming. And they have their own little bags and they be coming and toting the stuff from that market. I said, oh, they really do come here. I didn't realize that.

As she describes, the attendees were "just us" at the meetings held during off-hours at the market space, meaning that the residents were not sharing the space with the market visitors. This situation resulted in the customers' and volunteers' not being aware of this alternative use of the market's space for the neighborhood and also did not give the residents an opportunity to see the market in action. Alice described the market scene as "nice," but when asked if she has gone back to the market, she said no, because she cannot walk seven blocks to get there and because "I'm on a fixed income."

When asked how HMF could help the neighborhood, the residents seemed much less interested in the market operations or gardening on site. Some of the interviewees recalled the backyard gardening assistance that HMF had provided in collaboration with another local nonprofit organization during the first months of its operation and wanted to see it reinstated. Patricia, a resident interviewee, pointed out,

Like I said, those of us that live in this area are homeowners. And most of us are elderly, you know? So it's not easy to go to the 
farmers market. But if they can help us to get the ground in a condition where we could grow our own vegetables, yes, I would grow some vegetables.

Other suggestions by the residents in response to the question "What can HMF do for the neighborhood?" included involving young children and providing job training for youth, but the majority of the resident interviewees did not express a strong expectation that the organization should do more for the neighborhood.

By contrast, many customers and volunteers did not know much about the Hollygrove neighborhood, and the only time that they visited the area was to go to HMF. The following responses by one of the couples I interviewed exemplify a typical response to the question "What do you know about Hollygrove neighborhood?":

Scott: We're going down there, then we go down to Fig Street [where the market is located], take a right, take another right, go back to Carrolton [Avenue].

Carrie: It's like, yeah, we don't tend to spend time there, other than the market.

Author: You pointed out [earlier in the interview] that it doesn't particularly have a good reputation. But it's not something that would stop you from going to...

Carrie: No, it's not like an issue to me. I've biked there. I'm not concerned about it.

As these comments indicate, while these nonresident HMF supporters did not know much about the neighborhood or intend to spend more time there, none of them expressed concerns about being in the neighborhood. This lack of concern is notable, considering that most of these individuals were aware of the area's crime rates or lack of a good reputation. As mentioned earlier, the use of "Hollygrove" to denote HMF among nonresidents may indicate changing impressions about the neighborhood.

\section{Discussion and Conclusions}

This study illustrates how ideas about the community that HMF serves, or is expected to serve, vary among individuals who engage directly or indirectly with the organization. I did not detect signs that a cohesive "HMF community" is emerging among the participants and the local residents, but I found evidence of four communities, each with distinct ideas about how HMF could serve their needs. Overall, these communities - community gardeners, conspicuous locavores, hipsters, and local residents - view themselves as separate entities from HMF. For the gardeners and the locavores, HMF provided places to develop natural human capital (Macias, 2008) and social capital, respectively. Their engagements with HMF fits better with Bourdieus' (1984) definition of social capital than Putnam's (2000), since the individuals did not view their interactions with others as civic engagement. The hipsters valued the market and the volunteer opportunity as a way to exhibit their commitment to broader social concerns. Local residents who are not community gardeners may appear to be disconnected from HMF, though they also benefited by being able to use its space for community meetings. Despite sharing the same physical space, these communities had limited interaction.

At the organizational level, HMF lacks consensus on which communities it should serve or work with, in what ways it should do so, and whether these efforts should be a priority. At the same time, the staff collectively expressed a desire for HMF to do more "for the community." This lack of consensus could have contributed to the staff's limited ability to bring together the multiple communities that are already engaging with HMF. Yet some aspects of HMF's operational structure that were meant to increase community involvement may have ironically limited its community-building capacity. For example, customers are not required to have membership or volunteer their time to shop at the market, and its expanded business hours resulted in people not being at the market at the same time every week (this contrasts with when the market used to be open only one day a week for a few hours). Now, more people are utilizing HMF, but they have less structured interaction. The use of the space for community meetings 
during nonmarket hours meant that the residents did not come into contact with customers, volunteers, and gardeners.

Recent scholarship has highlighted the failure of the alternative food movement in engaging marginalized populations (Allen et al., 2008; Guthman, 2008; Hoover, 2013), specifically due to the lack of reflexivity in their practices (DuPuis \& Goodman, 2005; DuPuis, Harrison, \& Goodman, 2011). Considering such critique in the literature, the persistent disengagement across these groups, and especially the lack of interaction between Hollygrove residents and the other three groups, raises some concerns. Despite the concerns the HMF staff expressed about the social disconnects between the organization and the neighborhood in terms of race, class, age, and nativity, they were not able to bridge these communities. On this point I posit that the fact that HMF has not developed a cohesive community around its praxis does not necessarily mean that it lacks community-building capacity. The scholarship on the community-building capacity of the alternative food movement has typically focused on the quality and quantity of the social ties among the committed, core participants of the movement (e.g., Allen et al., 2008; DeLind, 1999; Nettle, 2014) and has evaluated the capacity in terms of whether a unified sense of community emerges from these interactions. This study shows that those who participate on the margins may also gain some social capital, although the connections may be fleeting and confined to intragroup interactions rather than making sustained ties across the communities.

In this regard, this paper illustrates the complexities of defining "community" in relation to the alternative food movement and identifying the expected outcomes of community building. The copresence of regulars and strangers, and the casual encounters and interactions among visitors at HMF, emulate what Oldenburg (1989) describes as the "third place," a neutral place for urbanites to enjoy a communal atmosphere free from the obligations of home and work. The third place's function is not to build community per se, but to expose heterogeneous urban residents to one another in a safe, leisurely, and not overtly political environment and to give them a sense of commu- nity and belonging. In the case of HMF, the market brings people with different interests and expectations to one place on a regular basis, and the HMF site symbolically connects growers, marketers, and consumers. It also brings mostly middle-class, predominantly White individuals to areas of the city that they would not have otherwise visited and allows them to have positive experiences and improve their impression of the area.

The changes that occurred as a result of HMF's establishment in the Hollygrove neighborhood are experienced both individually and collectively. The question remains how best to direct the emerging communities of varying interests and expectations toward new, broader social concerns and actions. Here, the solution may require the organization to go "beyond food" (Passidomo, 2013) in defining and engaging communities.

\section{Acknowledgements}

I thank Mary Soule for assistance in analyzing the interview data, as well as all the interviewees for their participation in the study. I also thank the Murphy Institute and the Committee on Research at Tulane University for providing funding for the project. I express gratitude to Karin Horler for her thorough copy-editing of the manuscript. Finally, I would like to thank the editor and the reviewers for their critical and constructive comments on an earlier draft of this paper, which helped to improve significantly its theoretical engagement with the current scholarship.

\section{References}

Alkon, A. H., \& Mares, T. M. (2012). Food sovereignty in US food movements: Radical visions and neoliberal constraints. Agriculture and Human Values, 29(3), 347-359. http://dx.doi.org/10.1007/s10460012-9356-Z

Alkon, A. H., \& McCullen, C. G. (2011). Whiteness and farmers markets: Performances, perpetuations . . . contestations? Antipode, 43(4), 937-959. http://dx.doi.org/10.1111/i.1467-8330.2010. 00818.x

Allen, J. O., Alaimo, K., Elam, D., \& Perry, E. (2008). Growing vegetables and values: Benefits of neighborhood-based community gardens for youth development and nutrition. Journal of Hunger \& Environmental Nutrition, 3(4), 418-439. http://dx.doi.org/10.1080/19320240802529169 
Andreatta, S., Rhyne, M., \& Dery, N. (2008). Lessons learned from advocating CSAs for low-income and food insecure households. Southern Rural Sociology, 23(1), 116-148. http://www.ag.auburn.edu/ auxiliary/srsa/index.htm

Armstrong, D. (2000). A survey of community gardens in upstate New York: Implications for health promotion and community development. Health \& Place, 6(4), 319-327. http://dx.doi.org/10.1016/S1353-8292(00)00013-7

Bourdieu, P. (1984). Distinction: A social critique of the judgement of taste (R. Nice, Trans.). Cambridge, Massachusetts: Harvard University Press.

Cox, R., Holloway, L., Venn, L., Dowler, L., Hein, J. R., Kneafsey, M., \& Tuomainen, H. (2008). Common ground? Motivations for participation in a community-supported agriculture scheme. Local Environment, 13(3), 203-218. http://dx.doi.org/10.1080/13549830701669153

Data Center, The. (2014). Neighborhood Statistical Area Data Profiles [online]. Retrieved June 25, 2014, from http://www.datacenterresearch.org/dataresources/neighborhood-data/

DeLind, L. B. (1999). Close encounters with a CSA: The reflections of a bruised and somewhat wiser anthropologist. Agriculture and Human V alues, 16(1), 3-9. http://dx.doi.org/10.1023/a:1007575521309

DeLind, L. B. (2002). Place, work, and civic agriculture: Common fields for cultivation. Agriculture and Human Values, 19(3), 217-224. http://dx.doi.org/10.1023/A:1019994728252

DuPuis, E. M., \& Goodman, D. (2005). Should we go "home" to eat? Toward a reflexive politics of localism. Journal of Rural Studies, 21(3), 359-371. http://dx.doi.org/10.1016/j.jrurstud.2005.05.011

DuPuis, E. M., Harrison, J. L., \& Goodman, D. (2011). Just food? In A. H. Alkon \& J. Agyeman (Eds.), Cultivating food justice: Race, class, and sustainability (pp. 283-307). Cambridge, Massachusetts: MIT Press.

Glaser, B. G., \& Strauss, A. L. (1999). The discovery of grounded theory: Strategies for qualitative research. New Brunswick, New Jersey: Transaction.

Glover, T. D. (2003). The story of the Queen Anne Memorial Garden: Resisting a dominant cultural narrative. Journal of Leisure Research, 35(2), 190-212. Retrieved from http://js.sagamorepub.com/jlr/article/view/605
Glover, T. D. (2004). Social capital in the lived experiences of community gardeners. Leisure Sciences, 26(2), 143-162. http://dx.doi.org/10.1080/01490400490432064

Greif, M. (2010, October 24). What was the hipster? New York Magazine. Retrieved from http://nymag.com/news/features/69129/

Guthman, J. (2008). "If they only knew”: Color blindness and universalism in California alternative food institutions. The Professional Geographer, 60(3), 387-397. http://dx.doi.org/10.1080/00330120802013679

Guthman, J. (2011). "If they only knew": The unbearable whiteness of alternative food. In A. H. Alkon \& J. Agyeman (Eds.), Cultivating food justice: Race, class, and sustainability (pp. 263-282). Cambridge, Massachusetts: MIT Press.

Hinrichs, C. C. (2000). Embeddedness and local food systems: Notes on two types of direct agricultural market. Journal of Rural Studies, 16(3), 295-303. http://dx.doi.org/10.1016/S0743-0167(99)00063-7

Hinrichs, C. C., \& Eshleman, J. (2014). Agrifood movements: Diversity, aims, and limits. In C. Bailey, L. Jensen \& E. Ransom (Eds.), Rural America in a globalizing world: Problems and prospects for the 2010s (pp. 138-155). Morgantown, West Virginia: West Virginia University Press.

Hinrichs, C. C., \& Kremer, K. S. (2002). Social inclusion in a Midwest local food system project. Journal of Poverty, 6(1), 65-90. http://dx.doi.org/10.1300/J134v06n01 04

Hollygrove Market and Farm. (n.d.). Who we are. Retrieved April 6, 2012, from http://hollygrovemarket.com/content/5670

Hoover, B. (2013). White spaces in Black and Latino places: Urban agriculture and food sovereignty. Journal of Agriculture, Food Systems, and Community Development, 3(4), 109-115. http://dx.doi.org/10.5304/jafscd.2013.034.014

Kingsley, J. Y., \& Townsend, M. (2006). 'Dig in' to social capital: Community gardens as mechanisms for growing urban social connectedness. Urban Policy and Research, 24(4), 525-537. http://dx.doi.org/10.1080/08111140601035200

Kurtz, H. (2001). Differentiating multiple meanings of garden and community. Urban Geography, 22(7), 656-670. http://dx.doi.org/10.2747/0272$\underline{3638.22 .7 .656}$ 
Lyson, T. A. (2004). Civic agriculture: Reconnecting farm, food, and community. Medford, Massachusetts: Tufts University Press.

Macias, T. (2008). Working toward a just, equitable, and local food system: The social impact of communitybased agriculture. Social Science Quarterly, 89(5), 1086-1101. http://dx.doi.org/10.1111/j.1540$\underline{6237.2008 .00566 . x}$

Morales, A. (2011). Growing food and justice: Dismantling racism through sustainable food systems. In A. H. Alkon \& J. Agyeman (Eds.), Cultivating food justice: Race, class, and sustainability (pp. 149-176). Cambridge, Massachusetts: MIT Press.

Nettle, C. (2014). Community gardening as social action. Farnham, UK: Ashgate.

Ohmer, M. L., Meadowcroft, P., Freed, K., \& Lewis, E. (2009). Community gardening and community development: Individual, social and community benefits of a community conservation program. Journal of Community Practice, 17(4), 377-399. http://dx.doi.org/10.1080/10705420903299961

Oldenburg, R. (1989). The great good place: Cafés, coffee shops, community centers, beauty parlors, general stores, bars, hangouts and how they get you through the day. New York: Paragon House.

Ostrom, M. R. (2007). Community supported agriculture as an agent of change: Is it working? In T. A. Lyson \& C. C. Hinrichs (Eds.), Remaking the North American food system: Strategies for sustainability (pp. 99-120). Lincoln: University of Nebraska Press. Passidomo, C. (2013). Going "beyond food":
Confronting structures of injustice in food systems research and praxis. Journal of Agriculture, Food Systems, and Community Development, 3(4), 89-93. http://dx.doi.org/10.5304/jafscd.2013.034.009

Putnam, R. D. (2000). Bowling alone: The collapse and revival of American community. New York: Simon and Schuster.

Saldivar-Tanaka, L., \& Krasny, M. E. (2004). Culturing community development, neighborhood open space, and civic agriculture: The case of Latino community gardens in New York City. Agriculture and Human V alues, 21(4), 399-412. http://dx.doi.org/10.1007/s10460-003-1248-9

Schmelzkopf, K. (1995). Urban community gardens as contested space. Geographical Review, 85(3), 364-381. http://dx.doi.org/10.2307/215279

Slocum, R. (2007). Whiteness, space and alternative food practice. Geoforum, 38(3), 520-533. http://dx.doi.org/10.1016/i.geoforum.2006.10.006

Veblen, T. (1899). The theory of the leisure class: An economic study of institutions. New York: Macmillan.

White, M. M. (2010). Shouldering responsibility for the delivery of human rights: A case study of the DTown farmers of Detroit. Race/Ethnicity: Multidisciplinary Global Contexts, 3(2), 189-211. http://www.jstor.org/stable/10.2979/RAC.2010.3. $\underline{2.189}$

Winter, M. (2003). Embeddedness, the new food economy and defensive localism. Journal of Rural Studies, 19(1), 23-32. http://dx.doi.org/10.1016/S0743-0167(02)00053-0 